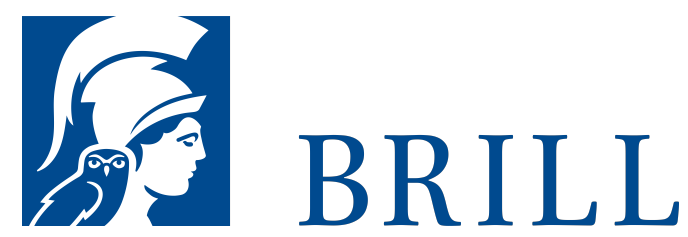

\title{
The Xenophon Papyri
}

Anabasis, Cyropaedia, Cynegeticus, De Vectigalibus

Author: Paap

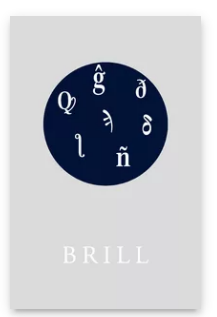

Pages: viii, $91 \mathrm{pp}$.

Language:

English

Subjects:

Ancient History,

Classical Studies

Publisher: Brill

\section{Series:}

Papyrologica

Lugduno-

Batava, Volume:

18

E-Book (PDF)

Released online:

$\mathrm{O} 2 \mathrm{Mar} 2 \mathrm{O} 2 \mathrm{O}$

ISBN: 978-90-

04-42770-9

List price

USD $\$ 70.00$

Paperback

Publication date:

o1 Dec 1970

ISBN: 978-90-

04-01703-O 
For more information see brill.com

Order information: Order online at brill.com +44330 333 0049 | customerservices@brill.com Submission information: brill.com/authors

Titles published by Brill | Fink, Brill | mentis or Brill | Schöningh: +49(o)715413279216| brill@brocom.de 